\title{
Glutamate Receptor Subunits GluR5 and KA-2 Are Coexpressed in Rat Trigeminal Ganglion Neurons
}

\author{
Yoshinori Sahara, ${ }^{1}$ Nobuhiro Noro, ${ }^{3}$ Yutaka lida, ${ }^{2}$ Kunimichi Soma, ${ }^{2}$ and Yoshio Nakamura ${ }^{1}$ \\ Departments of ${ }^{1}$ Physiology and ${ }^{2}$ Orthodontics, Faculty of Dentistry, Tokyo Medical and Dental University, Tokyo 113, \\ Japan, and ${ }^{3}$ Department of Pharmacology, Faculty of Medicine, University of Tokyo, Tokyo 113, Japan
}

\begin{abstract}
To determine the subunit composition of high-affinity kainate receptors in native neurons is a challenging problem because of the expression of more than one GluR subunit. In the present study the question of whether GluR5 and/or GluR6 subunits combine with KA-1 or KA-2 subunits in vivo is addressed by performing detailed physiological, pharmacological, and molecular characterization of functional kainate receptor channels in acutely dissociated trigeminal ganglion (TG) neurons. The results show that (1) smaller diameter TG neurons $(<30 \mu \mathrm{m})$ respond to L-glutamate and kainate, and the currents gated by kainate desensitize with prolonged agonist exposure; (2) all kainate receptor subunits are detected to some extent by reverse transcriptase-PCR, whereas glutamate receptor subunits GluR5 and KA-2 are expressed at high levels in the TG; (3) there
\end{abstract}

is an obvious similarity between the features of native kainate receptor channels in TG neurons and of heteromeric recombinant GluR5(R)/KA-2 channels in pharmacological properties, desensitization, rectification, ion permeability, and mean channel conductance; and (4) the age-dependent increase in GluR5 and KA-2 RNA levels in the TG is correlated well with an increased number of kainate-sensitive cells during postnatal development. Our data suggest that the heteromeric GluR5/ KA2 combination actually occurs in TG neurons and give a clue as to the subunit composition of native kainate receptor channels.

Key words: kainate receptor channel; GluR5; KA-2; trigeminal ganglion neurons; Concanavalin A; RT-PCR; Q/R editing
The non-NMDA ionotropic glutamate receptors have been classified into two different groups according to their binding affinities for the agonists AMPA and kainate. AMPA receptors are formed by four subunits, GluR1 through GluR4 (GluR-A through GluR-D) (Hollmann et al., 1989; Keinänen et al., 1990), and are involved in fast glutamatergic transmission in the mammalian CNS. Five subunits, GluR5 through GluR7 and KA-1 and KA-2, have been demonstrated to generate high-affinity kainate receptors in expression systems (Bettler et al., 1990, 1992; Egebjerg et al., 1991; Werner et al., 1991; Herb et al., 1992), but much less is known about the function of the kainate receptors. Kainate receptor channels are characterized by rapid desensitization of responses on application of kainate, which is greatly reduced by Concanavalin A (Egebjerg et al., 1991; Herb et al., 1992; Sommer et al., 1992). Recombinant experiments have demonstrated that (1) GluR5 and GluR6 subunits form functional homomeric channels when expressed in vitro (Egebjerg et al., 1991; Herb et al., 1992; Sommer et al., 1992); (2) homomeric KA-2 expression does not generate agonist-sensitive channels, but currents are observed when KA-2 is coexpressed with GluR5 or GluR6 subunits (Herb et al., 1992; Howe, 1996; Swanson et al., 1996); and (3) RNA editing of the $\mathrm{Q} / \mathrm{R}$ site, located in the second transmembrane domain (TMII) of GluR5 and GluR6 subunits, and the I/V and

Received Feb. 18, 1997; revised June 9, 1997; accepted June 18, 1997.

This work was supported by the Japanese Ministry of Education, Science, and Culture and the Uehara Memorial Foundation. We thank Drs. Craig Jahr, Hugh Robinson, and Gary Bennett for reading this manuscript.

Correspondence should be addressed to Dr. Yoshinori Sahara, Department of Physiology, Faculty of Dentistry, Tokyo Medical and Dental University, 1-5-45, Yushima, Bunkyo-ku, Tokyo 113, Japan.

Dr. Noro's present address: Yoshizato Morphomatrix Project, Exploratory Research for Advanced Technology, Japan Science and Technology Corporation, Tokyo, Japan.

Copyright (C) 1997 Society for Neuroscience $\quad 0270-6474 / 97 / 176611-10 \$ 05.00 / 0$
$\mathrm{Y} / \mathrm{C}$ sites, located in the TMI of the GluR6 subunit, is a critical determinant of the $\mathrm{Ca}^{2+}$ permeability and rectification properties of kainate receptor channels (Sommer et al., 1991; Egebjerg and Heinemann, 1993; Köhler et al., 1993).

Although native kainate receptor channels have been characterized in the DRG neurons (Huettner, 1990), in cultured hippocampal neurons (Paternain et al., 1995; Wilding and Huettner, 1997), and in glia cells (Patneau et al., 1994), the subunit composition of native kainate receptor channels remains unknown. To address the question of the molecular composition of native glutamate receptors, researchers recently have used a combination of whole-cell patch-clamp recording and PCR in single identified neurons and have shown that responses of kainate receptors in cultured hippocampal neurons match GluR6(Q) homomeric responses (Ruano et al., 1995). On the other hand, in situ hybridization studies have shown that the mRNAs encoding the five kainate receptor subtypes have distinct but overlapping patterns of expression in the brain (Wisden and Seeburg, 1993; Bahn et al., 1994), and immunoprecipitation studies of native brain membranes suggest that some kainate receptors probably exist in vivo as heteromeric assemblies of different types of subunit (Puchalski et al., 1994; Wenthold et al., 1994).

In the present study the question of whether GluR5 and/or GluR6 subunits combine with KA-1 or KA-2 subunits in vivo is addressed by performing a detailed characterization of kainate receptor channels in trigeminal ganglion (TG) neurons with the whole-cell patch-clamp and reverse transcriptase-PCR (RT-PCR) methods. Our results show that the functional properties of kainate receptor channels in TG neurons match those reported for recombinant heteromeric GluR5(R)/KA2 receptor channels and provide evidence that the heteromeric GluR5/KA2 combination actually occurs in native neurons. 


\section{MATERIALS AND METHODS}

Cell isolation and culture. Trigeminal ganglia were isolated from neonatal (2-14 d) or adult (2 month) Wistar rats. Dissected ganglia were incubated in Hank's solution (Life Technologies, Gaithersburg, MD) with papain (20 U/ml) (Worthington Biochemical, Freehold, NJ) and/or collagenase (590 U/ml) (Sigma, St. Louis, MO) dispase $(2.4 \mathrm{U} / \mathrm{ml})$ (Boehringer Mannheim, Mannheim, Germany) at $37^{\circ} \mathrm{C}$ for $20-30 \mathrm{~min}$. Cells were dissociated by trituration with a sterile Pasteur pipette and subsequently were plated onto poly-L-lysine pretreated $35 \mathrm{~mm}$ culture dishes at a density of $2 \times 10^{3}$ cells/plate. The plating medium contained Leibovitz's L-15 solution (Life Technologies), $10 \%$ fetal calf serum, penicillinstreptomycin $(20 \mathrm{U} / \mathrm{ml}), 26 \mathrm{mM} \mathrm{NaHCO}_{3}$, and $30 \mathrm{~mm}$ glucose. Cells were maintained in a humidified atmosphere of $95 \%$ air $/ 5 \% \mathrm{CO}_{2}$ at $37^{\circ} \mathrm{C}$. The cells were used for recording between 6 and $8 \mathrm{hr}$ after plating.

Electrophysiological recordings. Whole-cell recording was performed with an Axopatch 1-D amplifier (Axon Instruments, Foster City, CA) at room temperature. Cells were visualized under phase contrast on an inverted microscope (Olympus IX-70, Tokyo, Japan). Pipettes for wholecell recording contained (in $\mathrm{mm}$ ) $\mathrm{CsCl} 150, \mathrm{CaCl}_{2} 1, \mathrm{MgCl}_{2}$ 2, EDTA 11, and HEPES 10, pH 7.3; osmolarity was adjusted to $320 \mathrm{mOsm}$. Spermine $(100 \mu \mathrm{M})$ was added to prevent washout of intracellular polyamines (Bowie and Mayer, 1995; Kamboj et al., 1995). The extracellular solution contained (in mM) $\mathrm{NaCl} 160, \mathrm{KCl} 2.5, \mathrm{CaCl}_{2} 2, \mathrm{MgCl}_{2} 1, \mathrm{HEPES} 10$, glucose 10, and tetraethylammonium (TEA) chloride 5, with $1 \mu \mathrm{M}$ tetrodotoxin (TTX), pH 7.2 (osmolarity, $325 \mathrm{mOsm}$ ). An array of six quartz-glass tubes $(200 \mu \mathrm{m}$ in diameter, Polymicro Tech, Phoenix, AZ) was positioned within $200 \mu \mathrm{m}$ of neuronal cell bodies by using a mechanical manipulator (Narishige, Tokyo, Japan). Each flow tube was connected to a gravity-fed reservoir and controlled by a three-way solenoid valve. Neurons were always bathed in a flowing stream of control solution, except during the application of drugs. Rapid solution exchange was attained by switching the flow between adjacent flow tubes by simultaneously closing one valve and opening another. The solution exchange time constant was $\sim 20 \mathrm{msec}$, estimated by using the $10-90 \%$ rise time of responses to a saturating concentration of kainate $(200 \mu \mathrm{M})$ or L-glutamate $(1 \mathrm{~mm})$. In some experiments the array of flow tubes was moved with a piezoelectric bimorph (Vernitron, Bedford, $\mathrm{OH}$ ), and the solution exchange time constant was $<20 \mathrm{msec}$, as estimated, using a method described in Vyklicky et al. (1990). For noise analysis, solution flow was controlled manually, and the onset responses of kainate (200 $\mu \mathrm{M})$ varied from $200 \mathrm{msec}$ to $2-3 \mathrm{sec}$. Agonist applications were made at 70-120 sec intervals. Kainate, L-glutamate, quisqualate, NMDA, GABA, glycine, Concanavalin A (Con A), succinyl-Con A, and wheat germ agglutinin (WGA) were purchased from Sigma. 6-Cyano-7nitroquinoxaline-2,3-dione (CNQX), cyclothiazide (CTZ), and AMPA were purchased from Tocris Cookson (Bristol, UK). TTX was from Sankyo (Tokyo, Japan). The junction potential between internal and external solutions and the series resistance was compensated.

Ramp current-voltage ( $I-V$ ) relationships from -100 to $+100 \mathrm{mV}(0.2$ $\mathrm{V} / \mathrm{sec}$ ) were generated with pClamp (Axon Instruments). The $I-V$ relationships for kainate responses were leak-subtracted from a control response. Agonist-evoked currents were recorded on a PCM data recorder (TEAC RD-180T, band width DC to $20 \mathrm{kHz},-3 \mathrm{~dB}$ ). For the analysis of kainate-induced current noise and spectral densities, records were replayed from tapes, high-pass-filtered at $0.2 \mathrm{~Hz}$ and low-passfiltered at $2 \mathrm{kHz}$ (Bessel eight-pole, $48 \mathrm{~dB} / \mathrm{oct}$ ), and digitized with pClamp (sampling rate $5 \mathrm{kHz}$ ) on a computer (Compaq Prolinear 4/33i) with a TL-1 DMA digital interface. Digitized records were edited to remove artifacts and analyzed with an Axograph (Axon Instruments). Spectral densities were measured by a custom program (Robinson et al., 1991). Data are presented as mean \pm SEM. When statistical analysis was performed, ANOVA was used.

Reverse transcriptase-PCR. Total RNA was isolated from the TG and brains (cerebellum and hippocampus) of rats, aged P1, P3, P7, P14, and P56, using the guanidine thiocyanate method, followed by centrif ugation in cesium chloride solution. First-strand cDNA was synthesized from 5 $\mu \mathrm{g}$ of rat RNA with reverse transcriptase in the presence of random hexamer (First-strand cDNA synthesis kit, Pharmacia, Piscataway, NJ). The GluR1-4, GluR5, GluR6, GluR7, KA-1, and KA-2 subunits were amplified by PCR with the following set primers (from $5^{\prime}$ to $3^{\prime}$ ): GluR1-4 sense, CCTTTGGCCTATGAGATCTGGATGTG (position 1600-1625; Hollmann et al., 1989); GluR1-4 antisense, TCGTACCACCATTTGTTTTTCA (position 2327-2348); GluR5 sense, GCCCCTCTCACCATCACATAC (position 1730-1750; Bettler et al., 1990); GluR5 antisense, ACCTCGCAATCACAAACAGTACA (position 1893-1915);
GluR6 sense, TTCCTGAATCCTCTCTCCCCT (position 1963-1983; Egebjerg et al., 1991), GluR6 antisense, CACCAAATGCCTCCCACTATC (position 2182-2202); GluR7 sense, TGGAACCCTACCGCTACTCG (position 713-732; Bettler et al., 1992), GluR7 antisense, ACTCCACACCCCGACCTTCT (position 1096-1115); KA-1 sense, AGCGTTATGTCATGCCCAGACCAG (position 26-49; Werner et al., 1991), KA-1 antisense, AGGCATTCTGCTTTGGCACAGATGA (position 544-568); KA-2 sense, TGAGGAGGGGAGGAAGATGC (position 187-206; Herb et al., 1992); KA-2 antisense, TGCAGCTCAAAGATGTC (position 382-398). Rat glyceraldehyde-3-phosphate dehydrogenase (GAPDH; Clontech, Palo Alto, CA) was used as a control for the PCR. PCR was performed for 20 cycles of amplification with denaturing at $95^{\circ} \mathrm{C}$ for $30 \mathrm{sec}$, annealing at $55^{\circ} \mathrm{C}$ for KA-1 and KA-2 and $58^{\circ} \mathrm{C}$ for others for $1 \mathrm{~min}$, and elongating at $72^{\circ} \mathrm{C}$ for $1 \mathrm{~min}$ in the presence of $1 \times$ Vent buffer (New England Biolabs, Beverly, MA), $0.5 \mathrm{~mm}$ $\mathrm{dNTP}, 0.5 \mu \mathrm{M}$ each primer, and 1.25 U of AmpliTaq polymerase (PerkinElmer, Norwalk, CT). PCR products were separated by electrophoresis on $2.5 \%$ Metaphor agarose gel (FMC Bioproducts, Rockland, ME) containing $0.5 \mu \mathrm{g} / \mathrm{ml}$ ethidium bromide.

$R N A$ editing analysis. The regions across the $\mathrm{Q} / \mathrm{R}$ edited sequence, located in the second transmembrane domain, of GluR5 and GluR6 were amplified by PCR, using the cDNA as template. The PCR primers for GluR5 were as follows: $5^{\prime}$ primer, GTTTGTGATTGCGAGGTTCACA (22 mers); 3' primer, CAGGTTGGCCGTGTAGGATGA (21 mers). The amplified product was purified from the gel to remove residual nucleotides. The Q/R site of the GluR5 subunit was analyzed by digesting the PCR products with the restriction enzyme $B b v \mathrm{I}$ (New England Biolabs). $B b v I$ recognizes the sequence GCAGC, which is identical with the sequence of unedited GluR5 mRNA, but not the edited sequence GCGGC. The digestion of the PCR-generated fragment (233 bp) was expected to be cut into two fragments (139 and $94 \mathrm{bp})$. The PCR primers for GluR6 were as follows: 5' primer, TTCCTGAATCCTCTCTCCCCT (21 mers); 3' primer, CACCAAATGCCTCCCACTATC (21 mers). The Q/R site of the GluR6 subunit was analyzed by digesting the PCR products with the restriction enzyme AciI (New England Biolabs). $A c i$ I recognizes the sequence CCGC of the edited version of GluR6 (coding for $\mathrm{R}$ ), but not that of the unedited version. The digestion of the PCR-generated fragment $(259 \mathrm{bp})$ predicts two fragments of 197 and 62 bp. After $1 \mathrm{hr}$ of incubation with $\mathrm{BbvI}$ or $\mathrm{AciI}$ at $37^{\circ} \mathrm{C}$, the digests were separated on a $2.5 \%$ Metaphor agarose gel, supplemented with ethidium bromide.

Northern blot analysis. Total RNA was isolated from TG of rats of various ages (P1, P3, P7, P14, P28, and P56), using the guanidine thiocyanate procedure. RNA samples $(10 \mu \mathrm{g} / \mathrm{lane})$ were electrophoresed through a $1.4 \%$ agarose-formaldehyde denaturing gel and transferred onto GeneScreen Plus membranes. The blot was hybridized with ${ }^{32} \mathrm{P}$ labeled cDNA probes specific for GluR5, KA-1, or KA-2 at $42^{\circ} \mathrm{C}$ for $1 \mathrm{hr}$ and washed in high-stringency condition with $0.1 \times \mathrm{SSC} / 0.5 \% \mathrm{SDS}$ at $65^{\circ} \mathrm{C}$; autoradiography was performed on Kodak X-Omat AR5 film (Rochester, NY) with an intensifying screen at $-80^{\circ} \mathrm{C}$ for $18 \mathrm{hr}$.

\section{RESULTS}

\section{Expression of kainate receptor subunit RNAs in the TG}

To determine which glutamate receptor subunits are expressed in the TG, we examined the expression of the GluR1-4, GluR5, GluR6, GluR7, KA-1, and KA-2 transcripts. Total cellular RNA was isolated and analyzed by RT-PCR. PCR primers for the GluR5, GluR6, GluR7, KA-1, and KA-2 subunits were derived from specific sites for each kainate receptor subunit, and a primer for AMPA receptor subunits (GluR1-4) was derived from a highly conserved region among AMPA receptors. The predicted sizes of the PCR-generated fragments were 750, 208, 259, 421, 566, and 228 bp for the GluR1-4, GluR5, GluR6, GluR7, KA-1, and KA-2 subunits, respectively. As shown in Figure 1, PCR products for all subunits were detected in the TG, although a greater degree of variation in the expression of GluR subunits was apparent in the TG than in the cerebellum and hippocampus. In both P7 and adults the expression of GluR5, KA-1, and KA-2 subunits was high, but GluR6 and GluR7 were seen only at a barely detectable level in the TG. 

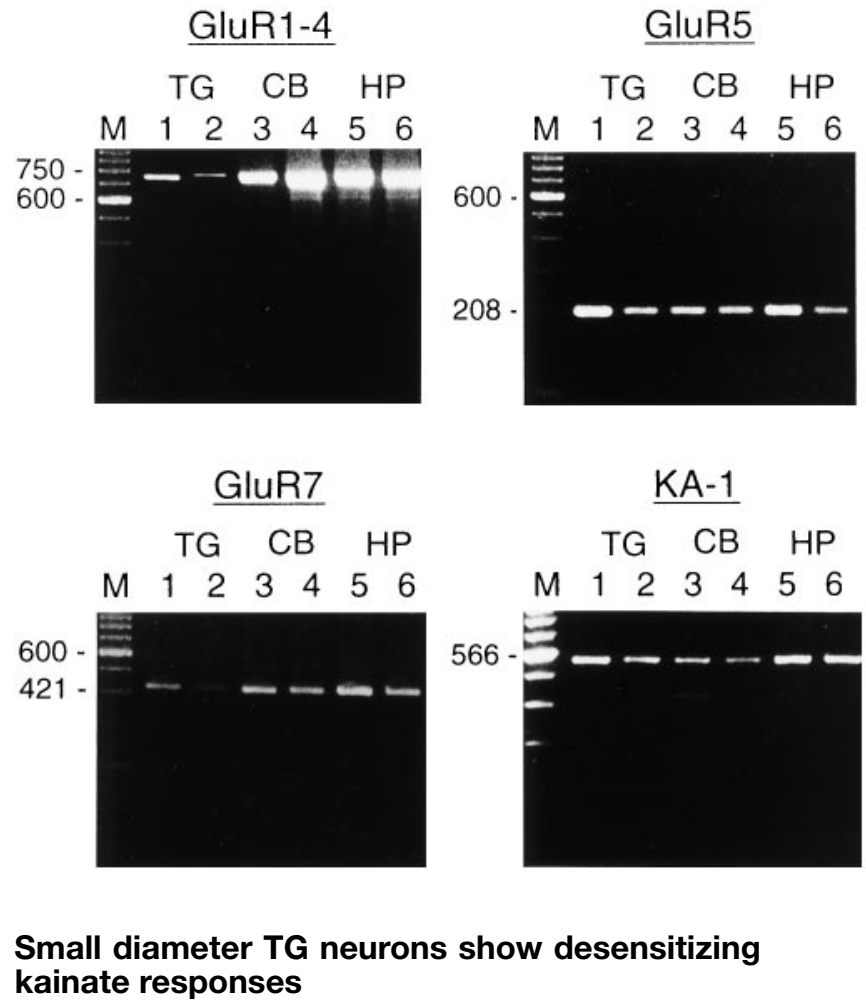

\section{Small diameter TG neurons show desensitizing kainate responses}

Acutely dissociated TG neurons from P4-P8 rats were tested with several excitatory and inhibitory amino acids, including L-glutamate, kainate, quisqualate, AMPA, NMDA, GABA, and glycine. Of 70 cells tested, all cells responded to GABA $(100 \mu \mathrm{M})$ (Fig. 2A). Approximately $50 \%$ of TG neurons for which the diameter was smaller than $30 \mu \mathrm{m}$ responded to L-glutamate (1 $\mathrm{mm})$ and kainate $(200 \mu \mathrm{M})$. Two types of TG neurons (large light and small dark neurons) have been described on the basis of cytoplasmic appearance under the light microscope; however, none of the large diameter neurons $(>30 \mu \mathrm{m})$ responded to kainate. Figure $2 C$ shows currents evoked in a TG neuron by five doses of kainate, ranging from 1 to $200 \mu \mathrm{M}$. Responses increased in amplitude with increasing agonist dose, up to maximal levels at $\sim 200 \mu \mathrm{M}$. The $\mathrm{EC}_{50}$ was $13.7 \pm 0.8 \mu \mathrm{M}$ (Hill coefficient, $1.3 \pm 0.1$; six trials in four cells) (Fig. $2 D$ ). The peak amplitude of kainate currents ranged from barely detectable to a maximum of $180 \mathrm{pA}$, with a mean of $63.4 \pm 5.8 \mathrm{pA}(n=41)$ at $-80 \mathrm{mV}$. Prolonged application of kainate produced an initial peak of current that decayed over several seconds to reach a steady-state level at $\sim 10 \%$ of the peak response. The extent of desensitization was quantified by the $I_{\mathrm{ss}} / I_{\text {peak }}$ ratio, where $I_{\text {ss }}$ (steady-state current amplitude) was measured at $50 \mathrm{sec}$ after agonist application, and $I_{\text {peak }}$ represents the peak amplitude. In the TG neurons, the $I_{\text {ss }} / I_{\text {peak }}$ value was $0.14 \pm 0.03$. The kainate response was reversibly antagonized by CNQX (20 $\mu \mathrm{M})$ (Fig. $2 B)$. We never encountered a TG neuron that responded to AMPA (up to $1 \mathrm{~mm}$ ), quisqualate (up to $0.5-1 \mathrm{~mm}$ ), NMDA (up to $1 \mathrm{~mm}$ ), or glycine (up to $500 \mu \mathrm{M}$ ).

\section{Expression of functional kainate receptors in TG neurons}

To assess which glutamate receptor subunits are functionally expressed in TG neurons, we performed detailed pharmacological, physiological, and molecular characterization of kainate receptor channels, using the whole-cell patch-clamp technique and RT-PCR.

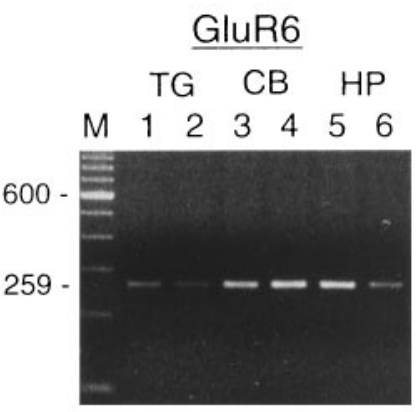

Figure 1. RT-PCR to identify GluRs subunit expression in the TG. RNAs from tissues were reverse-transcribed and subjected to PCR, using primers specific for each kainate receptor subunit (GluR5, GluR6, GluR7, $K A-1$, and $K A-2$ ) and for a highly conserved region among AMPA receptor subunits (GluR1-4). Tissues analyzed included trigeminal ganglion $(T G)$, cerebellum $(C B)$, and hippocampus $(H P)$ of 7-d-old (oddnumbered lanes) and 56-d-old rats (evennumbered lanes). Equal volumes of PCR product were analyzed in each lane. Lanes marked $M$ contain a 100 bp ladder.
Con $A$ and $W G A$, but not CTZ, suppress desensitization

We examined the effect of lectins and CTZ on the desensitization of kainate responses. Exposure to Con A (300 $\mu \mathrm{g} / \mathrm{ml}$ for $3 \mathrm{~min}$ ) augmented the peak kainate currents and partially eliminated desensitization of kainate responses (Fig. 3A). The effects of Con A persisted even after the neurons were washed with control solution. In 17 cells tested before and after Con A treatment, the peak current elicited by kainate increased significantly (2.4-fold \pm $0.3 ; p<0.05)($ Fig. $3 D)$, and the extent of desensitization $\left(I_{\mathrm{ss}} / I_{\text {peak }}\right.$ ratio) was reduced significantly $(0.62 \pm 0.02 ; p<0.05)$ (Fig. $3 E)$. Con $\mathrm{A}$ did not change the $\mathrm{EC}_{50}$ for kainate $(14.4 \pm 1.1 \mu \mathrm{M}$; Hill coefficient, $1.0 \pm 0.1$; five trials in three cells). The effects of Con A were both dose-dependent $\left(\mathrm{EC}_{50}=62.7 \mu \mathrm{g} / \mathrm{ml} ; n=3\right.$ ) (Fig. $4 A$ ) and time-dependent. Figure $4 B$ shows that the onset of action of Con A was fit reasonably well by a single exponential curve with a time constant of $0.96 \min (n=3)$. However, substantial desensitization persisted even after prolonged treatment with Con A.

In addition to Con A, WGA and succinyl-Con A reduced desensitization to L-glutamate and kainate. WGA applied at 300 $\mu \mathrm{g} / \mathrm{ml}$ was much less effective than Con A in blocking desensitization of the response to kainate in TG neurons: normalized peak amplitude, $0.89 \pm 0.03 ; I_{\mathrm{ss}} / I_{\text {peak }}$ ratio, $0.38 \pm 0.01(n=13)$ (Fig. $3 B, D, E)$. The ability to modulate desensitization of kainate responses in TG neurons also was mimicked by succinyl-Con A (300 $\mu \mathrm{g} / \mathrm{ml}$ ), a dimeric form of Con A that does not cross-link receptors. This suggests that Con A works mainly in ways other than cross-linking. Considering that Con A interacts with $\alpha$-mannose or $\alpha$-glucose, that WGA specifically binds $N$-acetylglucosamine and $N$-acetylneuraminic acid, and that amino acid sequence analysis for glutamate receptors subunits predicts multiple N-linked glycosylation sites in GluR5-GluR7 and KA-1 and 2 subunits, it seems that glycosylation contributes to the desensitization of kainate currents.

Cyclothiazide $(100 \mu \mathrm{M})$, which modulates responses to glutamate at non-NMDA receptors, also was tested for its effect on the desensitizing response to kainate in TG neurons (Fig. 3C). How- 


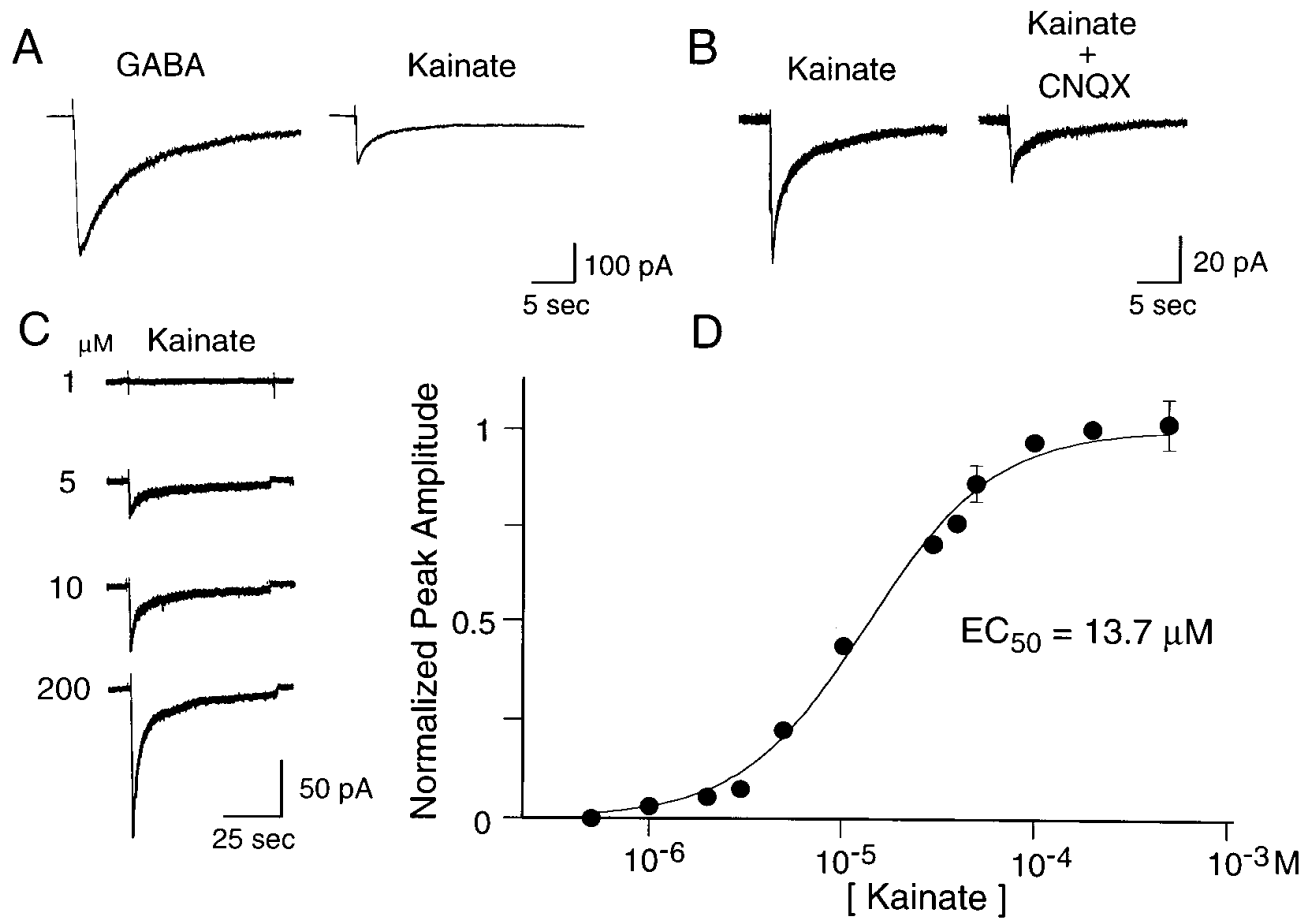

Figure 2. Whole-cell currents evoked by kainate in TG neurons. $A$, Kainate $(200 \mu \mathrm{M})$ and GABA $(100 \mu \mathrm{M})$ produced desensitizing responses in a small diameter TG neuron. $B$, CNQX (20 $\mu \mathrm{M})$ inhibited kainate currents. $C$, Currents activated by 1-200 $\mu \mathrm{M}$ kainate in a TG neuron. $D$, Dose-response data for kainate from four TG neurons. Concentration-response curve was fit with the function $I=I_{\max } \cdot\left\{1 /\left(1+(K /[\text { agonist }])^{n}\right)\right\}$, where $K$ represents the half-maximal effective concentration $\left(\mathrm{EC}_{50}\right)$ and $n$ denotes the Hill coefficient. $\mathrm{EC}_{50}$ was $13.7 \pm 0.8 \mu \mathrm{M}$; the Hill coefficient was 1.3 \pm 0.1 . Holding potential was $-80 \mathrm{mV}$.

Figure 3. Con A and WGA, but not CTZ, modulate desensitization of kainate currents. $A$, Con A $(300 \mu \mathrm{g} / \mathrm{ml}$ for 3 min) irreversibly increased peak kainate currents and strongly attenuated desensitization. $B$, WGA $(300 \mu \mathrm{g} / \mathrm{ml}$ for $3 \mathrm{~min})$ irreversibly attenuated desensitization to kainate. $C$, CTZ $(100 \mu \mathrm{M})$ did not change the kainate response. $D$, Peak amplitudes of kainate responses, normalized to the control response to kainate, after treatment with Con A, WGA, and CTZ. An asterisk indicates that Con A increased the peak current elicited by kainate significantly $(p<$ $0.05) . E, I_{\mathrm{ss}} / I_{\text {peak }}$ for kainate responses before and after treatment with Con A, WGA, and CTZ. Asterisks indicate that Con A and WGA reduced the extent of desensitization significantly $(p<0.05)$. Cells were treated with $0.3 \mathrm{mg} / \mathrm{ml}$ Con A or $0.3 \mathrm{mg} / \mathrm{ml} \mathrm{WGA} \mathrm{for}>3 \mathrm{~min}$ before application of kainate. Error bars show SEM. Numbers in parentheses show the number of recorded cells. Holding potential was $-80 \mathrm{mV}$.
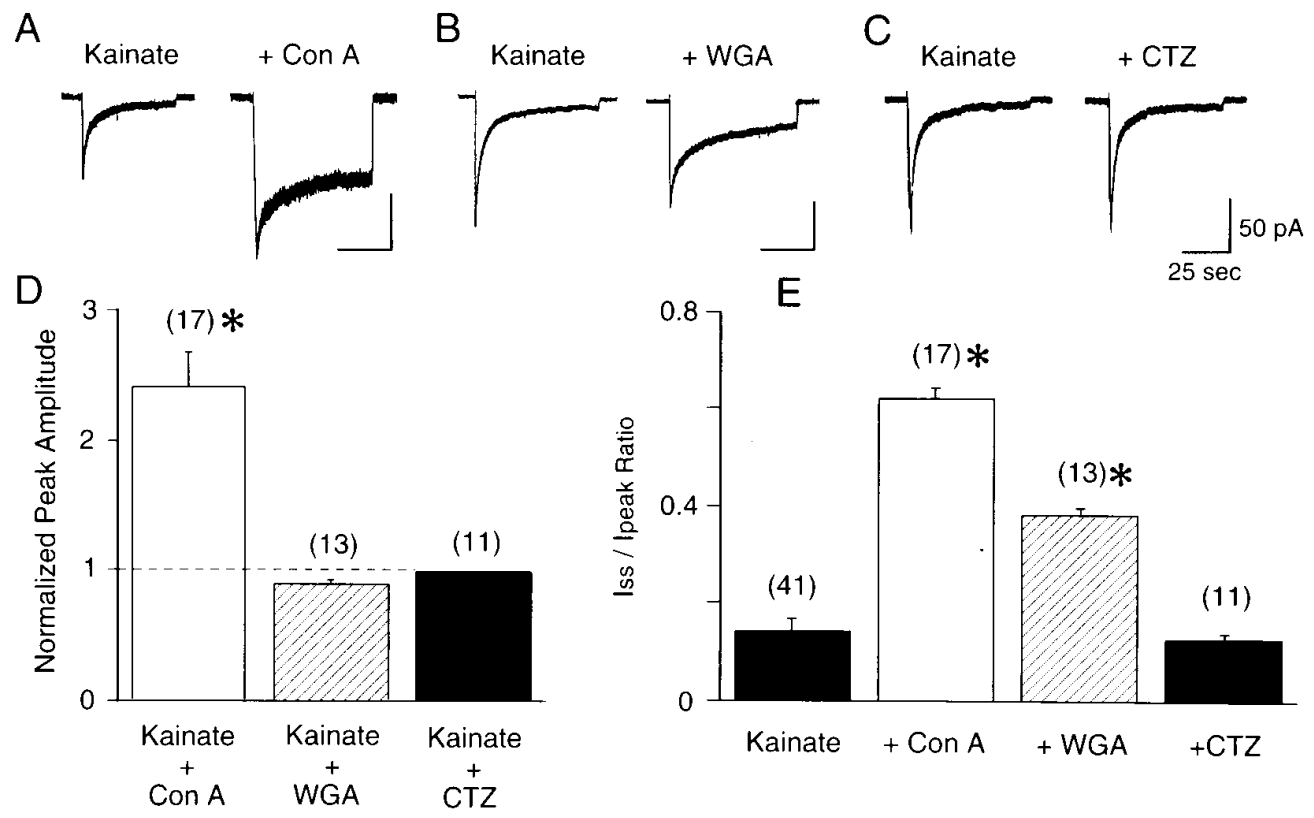

ever, it produced neither potentiation of the peak kainate current nor reduction in the degree of desensitization of kainate responses in TG neurons (normalized peak amplitude, $0.98 \pm 0.01$; $I_{\text {ss }} / I_{\text {peak }}$ ratio, $\left.0.13 \pm 0.01 ; n=11\right)$ (Fig. $\left.3 D, E\right)$.

As summarized in Figure 3,D and $E$, desensitization of kainate responses in TG neurons was modulated strongly by Con A but it was insensitive to cyclothiazide. Considering that CTZ selectively modulates AMPA receptor subunits, but not kainate receptors (Partin et al., 1993), functional expression of AMPA receptors in the TG seems unlikely.

Time course of desensitization of kainate responses

The time constants of desensitization have been shown to be affected by the subunit composition in recombinant kainate re-

ceptor channels (Herb et al., 1992). We analyzed the time course of desensitization of kainate responses in TG neurons, using a piezo-driven application system. Figure 5, $A$ and $C$, shows the current evoked by a saturating dose of kainate $(200 \mu \mathrm{M})$. With prolonged agonist applications, lasting several minutes, the currents appeared to reach a steady-state level of $\sim 10 \%$ of the peak response to kainate. The onset of desensitization of kainate currents was well fit by the sum of two exponentials. In this case the faster time constant was $123.9 \mathrm{msec}$ and the slower one was 1.3 sec. The mean values for nine TG neurons were $\tau_{1}=128.1 \pm 8.1$ msec and $\tau_{2}=1.3 \pm 0.1 \mathrm{sec}$. Figure 5, $B$ and $D$, shows responses to $1 \mathrm{~mm} \mathrm{~L}$-glutamate, which shows a fast current component $\left(\tau_{1}=\right.$ $33.7 \mathrm{msec})$ and a slow component $\left(\tau_{2}=221.5 \mathrm{msec}\right)$. The mean 
A

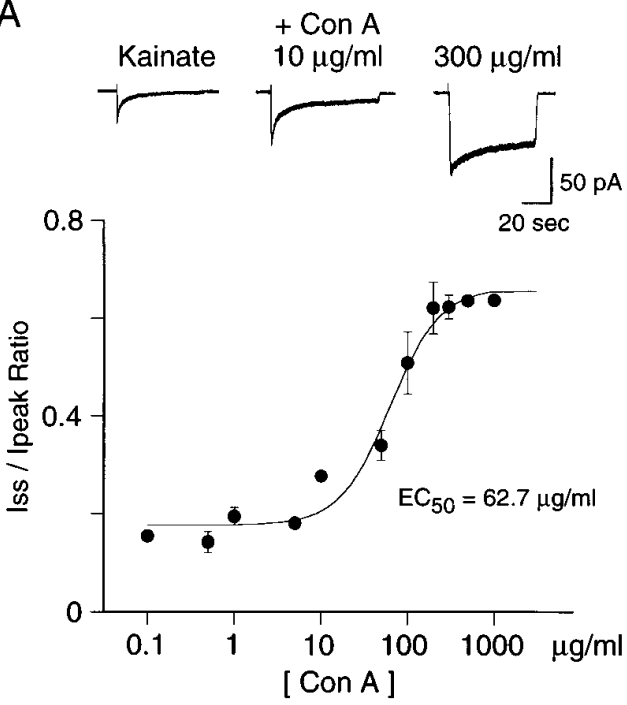

B

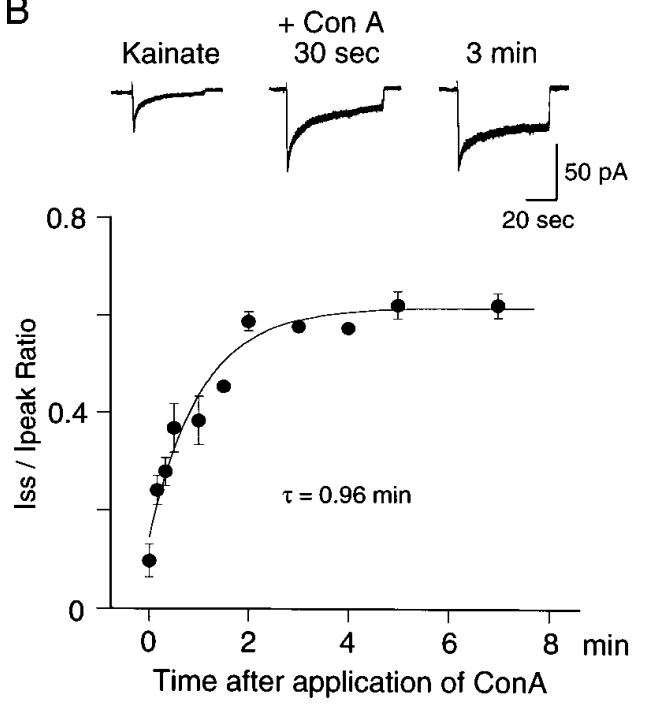

Figure 4. Dose- and time-dependent effects of Con $\mathrm{A}$ on desensitizing kainate responses. $A$, Dose-response curve for desensitization by Con A. $I_{\text {ss }} / I_{\text {peak }}=$ $I_{\text {ss }} / I_{\text {peak }_{\max }} \cdot\left\{1 /\left(1+(K /[\text { Con } \mathrm{A}])^{n}\right)\right\}+$

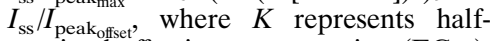
maximal effective concentration $\left(\mathrm{EC}_{50}\right)$, $n$ denotes the Hill coefficient, and $I_{\mathrm{ss}} / I_{\text {peak }_{\text {offset }}}$ corresponds to the $I_{\mathrm{ss}} / I_{\text {peak }}$ values of kainate response in the absence of Con A. $\mathrm{EC}_{50}$ was $62.7 \pm 11.7$ $\mu \mathrm{g} / \mathrm{ml}$; the Hill coefficient was $1.5 \pm 0.5$ $(n=3)$. Top traces show responses to 200 $\mu \mathrm{M}$ kainate recorded in the absence and in the presence of Con A (10 and 300 $\mu \mathrm{g} / \mathrm{ml})$. $B$, Time course of the onset of Con A-evoked potentiation of kainate responses. The curve was fit with an exponential function. Top traces show responses to $200 \mu \mathrm{M}$ kainate recorded before and after application of Con A (30 $\mathrm{sec}$ and $3 \mathrm{~min})$. Con A (300 $\mu \mathrm{g} / \mathrm{ml}$ for 3 min) did not completely eliminate desensitization.

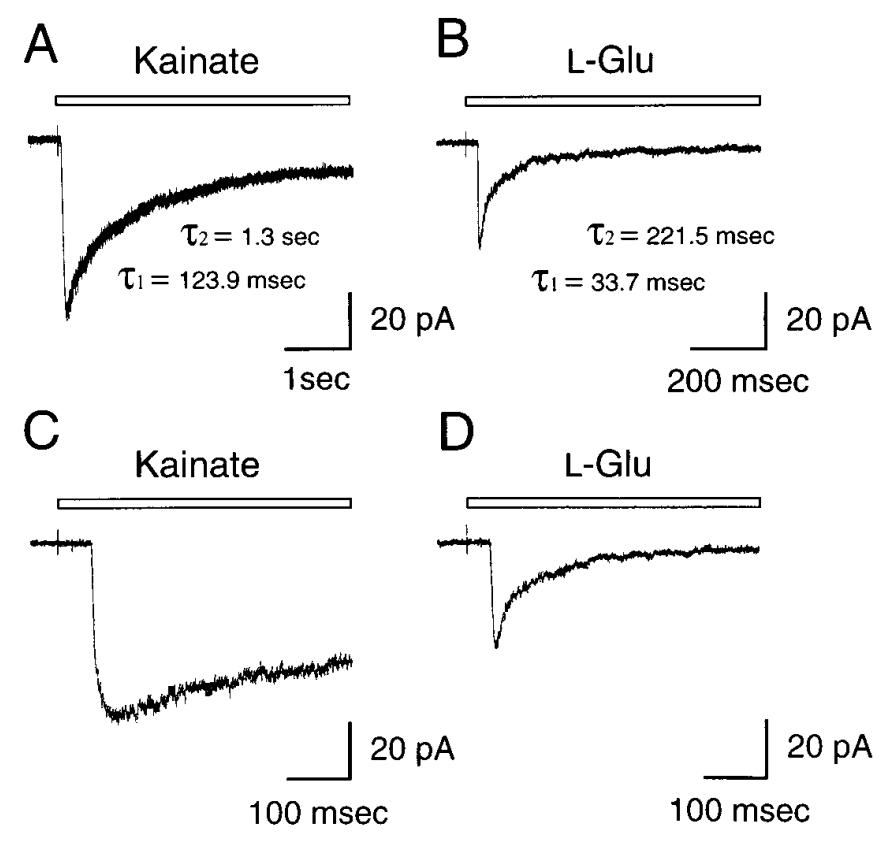

Figure 5. Time course of desensitization of kainate $(200 \mu \mathrm{M})$ and L-glutamate $(1 \mathrm{mM})$ currents. Desensitization time constants were determined by fitting the decay phase with the sum of two exponentials. $A$, The decay time constants of kainate currents $(200 \mu \mathrm{M})$ in TG neurons were $\tau_{1}$ $=123.9 \mathrm{msec}$ and $\tau_{2}=1.3 \mathrm{sec}$. $B$, A response to $1 \mathrm{~mm} \mathrm{~L}$-glutamate. A fast current component $\left(\tau_{1}=33.7 \mathrm{msec}\right)$ and a slow component $\left(\tau_{2}=221.5\right.$ $\mathrm{msec}$ ) were observed. The fitted range extended to $3 \mathrm{sec}$ after the peak. $C$, $D$, Fast sweeps of the records in $A$ and $B$, respectively. Holding potential was $-80 \mathrm{mV}$.

values for three TG neurons were $\tau_{1}=33.3 \pm 2.5 \mathrm{msec}$ and $\tau_{2}=$ $239.2 \pm 30.6 \mathrm{msec}$.

Results from recombinant experiments with whole-cell recordings that used a rapid perfusion system (Herb et al., 1992) have shown that responses for homomeric GluR6(Q) or GluR6(R) and the combination GluR6(Q)/KA-2 are rapidly and completely desensitizing, unlike those in TG neurons. Homomeric recombinant receptors generated from GluR5(Q) showed slow desensitization $\left(\tau_{1}=15.3 \mathrm{msec}\right.$ and $\left.\tau_{2}=281 \mathrm{msec}\right)$, whereas GluR5(R) was inactive unless it was combined with other subunits (Herb et al., 1992; Sommer et al., 1992) or had an extremely low conductance (Swanson et al., 1996). For the combination GluR5(Q)/ KA-2, the desensitization was more rapid $\left(\tau_{1}=15.1 \mathrm{msec}\right.$ and $\tau_{2}$ $=688 \mathrm{msec}$ ) than that observed in TG neurons, but for GluR5(R)/KA-2, desensitization was like that seen in TG neurons. Together, these results suggest that the major glutamate receptor in TG neurons is likely to be composed of GluR5, not GluR6, in combination with KA-2.

Colquhoun et al. (1992) reported that the rise time of the AMPA receptor-mediated current in the hippocampal slice was 0.2-0.6 msec, the decay time constant of the current after short pulses of $1 \mathrm{~mm}$ L-glutamate was $\sim 3.0 \mathrm{msec}$, and the time constant for desensitization was $\sim 10 \mathrm{msec}$ for patches from hippocampal neurons. Thus, it is likely that the time constant of desensitization in the present experiments is determined mainly by the speed of agonist application. Kinetics of native kainate receptor channels still remain to be elucidated.

\section{Current-voltage relation}

It has been demonstrated that the presence of a glutamine $(\mathrm{Q})$ or an arginine $(\mathrm{R})$ residue in the $\mathrm{Q} / \mathrm{R}$ site of GluR5 and GluR6 subunits and at the $\mathrm{I} / \mathrm{V}$ and $\mathrm{Y} / \mathrm{C}$ sites of the GluR6 subunit are critical determinants of $\mathrm{Ca}^{2+}$ permeability and rectification of kainate receptor channels (Sommer et al., 1991; Egebjerg and Heinemann, 1993; Köhler et al., 1993). In particular, editing of the Q/R site in the GluR6 subunit seems to govern the rectification properties of homomeric GluR6 channels (Egebjerg and Heinemann, 1993; Köhler et al., 1993).

Q/R editing. We analyzed the extent of GluR5 editing in RNAs extracted from both the TG and the cerebellum. After RT-PCR, the $B b v$ I digestion of the PCR products was analyzed. In a typical experiment with rat TG (P7) and cerebellum (P14) PCR products, ethidium bromide staining of an agarose gel revealed amplification products of $233 \mathrm{bp}$ (Fig. $6 \mathrm{~A}$, left). $B b v \mathrm{I}$ digested the PCR product from unedited GluR5 subunit and completely cut it into two smaller fragments (139 and $94 \mathrm{bp}$ ), whereas the fraction from edited GluR5 subunit was not cut by $B b v 1$. As shown in Figure $6 A$ (right), gel analysis revealed three fragments $(233,139$, and $94 \mathrm{bp}$ ) in both the TG and cerebellum, suggesting that both the edited and unedited forms are expressed. Because it has been reported that $40 \%$ of GluR5 mRNA is edited in the cerebellum at 
A $-B b v l$ 122334 M 56 $---\ldots-$

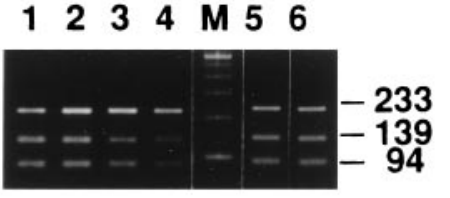
B -Acil + Acil

$\begin{array}{lllllll}1 & 2 & 3 & 4 & M & 5 & 6\end{array}$

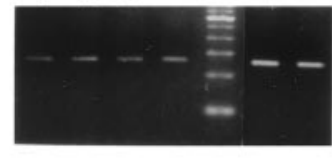
12234 M 56

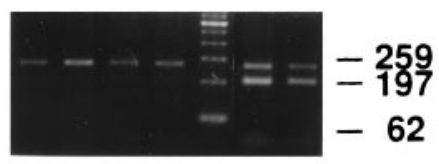

C

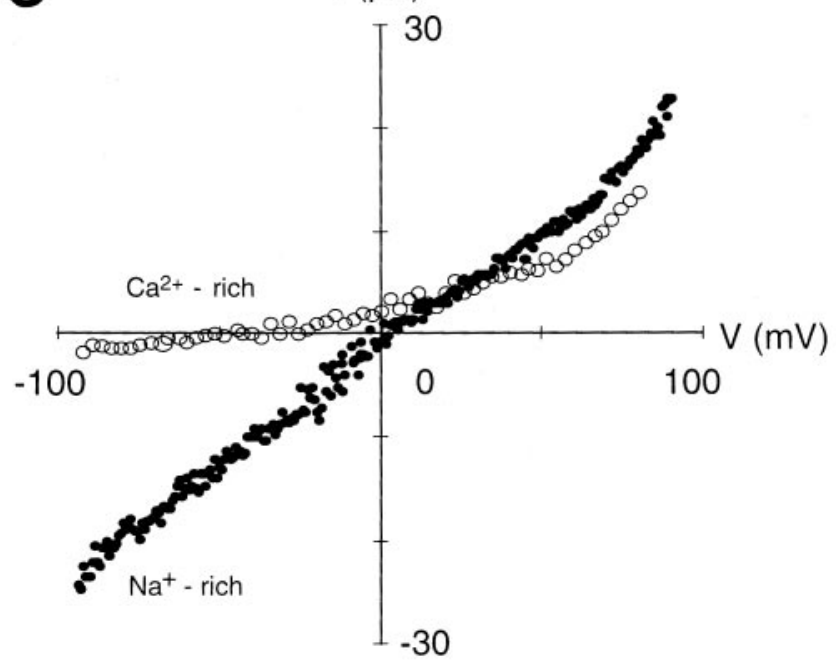

Figure 6. RNA editing analysis of the Q/R site of the GluR5 and GluR6 subunit in the TG and $I-V$ relationships of the kainate-induced responses in a TG neuron. $A$, RNA editing analysis of the $\mathrm{Q} / \mathrm{R}$ site of the GluR5 fragment. RNA editing of the $\mathrm{Q} / \mathrm{R}$ site was analyzed by isolating total RNA from the TG, reverse transcription into cDNA, PCR across the edited region with GluR5 specific primers, and restriction analysis of the PCR products with $B b v I$. Shown are ethidium bromide-stained agarose gels of the PCR products (left, expected size $233 \mathrm{bp}$ ) and the PCR products incubated with $B b v$ I (right, expected fragment sizes 139 and 94 bp). Lanes 1-4, TG samples taken from P3, P7, P14, and P56; lane 5, cerebellum sample from P14; lane 6, hippocampal sample from P7. Lanes marked $M$ contain a 100 bp ladder. $B$, RNA editing analysis of the $\mathrm{Q} / \mathrm{R}$ site of the GluR6 fragment. Shown are ethidium bromide-stained agarose gels of the GluR6 PCR products (left, expected size $259 \mathrm{bp}$ ) and the PCR products incubated with AciI (right, expected fragment sizes 197 and 62 bp). Lanes 1-4, GluR6 TG samples taken from P3, P7, P14, and P56; lane 5, hippocampal sample from P7; lane 6, cerebellum sample from P14. Lanes marked $M$ contain a marker. $C$, Current-voltage $(I-V)$ relations of kainate-activated $(200 \mu \mathrm{M})$ currents in a TG neuron with $\mathrm{Na}^{+}$-rich extracellular solution ( filled circles) and $\mathrm{Ca}^{2+}$-rich solution (open circles). Recordings were performed after $3 \mathrm{~min}$ of Con A ( $300 \mu \mathrm{g} / \mathrm{ml})$ treatment. The $I-V$ relation was recorded by using a voltage ramp from -100 to +100 $\mathrm{mV}(0.2 \mathrm{~V} / \mathrm{sec})$ and by subtracting the $I-V$ curve obtained before and after $200 \mu \mathrm{M}$ kainate application.

P4-P25, with the degree of editing increasing to $80 \%$ in the adult (Paschen et al., 1995), we analyzed the extent of GluR5 editing during the course of postnatal development (P3, P14, and P56). In the TG, both the edited and unedited forms of the GluR5 subunit were detected at all ages (Fig. 6A, right).
We also determined the extent of GluR6 editing in the TG, although PCR products of GluR6 were barely detectable. AciI restriction enzyme cuts the edited version of GluR6 (coding for $\mathrm{R}$ ) but cuts neither the unedited version (coding for $\mathrm{Q}$ ) nor GluR5. The AciI digestion of the GluR6 PCR-generated fragment $(259 \mathrm{bp})$ predicts two fragments of 197 and $62 \mathrm{bp}$. In agreement with the report that GluR6 mRNA is edited by 50$60 \%$ at the $\mathrm{Q} / \mathrm{R}$ site in the hippocampus (Bernard and Khrestchatisky, 1994), gel analysis revealed three fragments in the hippocampus (P7) (Fig. 6B, right). However, the GluR6 subunit in the TG was nearly exclusively in the unedited form at all ages (Fig. 6B, right).

$\mathrm{I}-\mathrm{V}$ relation and $\mathrm{Ca}^{2+}$ permeability. The $I-V$ relationship of the steady-state kainate currents in TG neurons was measured by applying voltage ramps. To prevent washout of intracellular polyamine, which produces linear instead of inwardly rectifying $I-V$ relationships of the kainate response (Bowie and Mayer, 1995; Kamboj et al., 1995), we included spermine $(100 \mu \mathrm{M})$ in the patch pipettes. In all TG neurons tested, the $I-V$ relation for kainate was approximately linear or slightly outwardly rectifying. Figure $6 C$ shows the $I-V$ relation for kainate from $-100 \mathrm{mV}$ to $+90 \mathrm{mV}$. In $\mathrm{Na}^{+}$-rich $(160 \mathrm{~mm})$ extracellular solution, the reversal potential of the kainate-activated current was close to $0 \mathrm{mV}(-2.4 \pm 0.4$ $\mathrm{mV} ; n=44)$. The ratio of conductances $\left(G_{+40} / G_{-60}\right)$ was taken as the rectification index, which had a mean value of $0.81 \pm 0.05$ $(n=44)$ in TG neurons. Inward current at negative membrane potentials was recorded in high extracellular $\mathrm{Na}^{+}$but was barely detectable in high extracellular $\mathrm{Ca}^{2+}$ solution $\left(10 \mathrm{mM} \mathrm{Ca}^{2+}+\right.$ $150 \mathrm{~mm} \mathrm{NMG})$. In the high extracellular $\mathrm{Ca}^{2+}$ solution the reversal potential of the kainate-activated current shifted to $-37.5 \pm 7.7 \mathrm{mV}(n=4)$. Variations of the extracellular $\mathrm{Ca}^{2+}$ concentration $(0.1-10 \mathrm{~mm})$ had no measurable effect on the $I-V$ relation. These indicate a low $\mathrm{Ca}^{2+}$ permeability of kainate receptor channels in the TG neurons.

The slightly outward rectification of the steady-state $I-V$ relationship and the low $\mathrm{Ca}^{2+}$ permeability of kainate receptor channels in TG neurons match the properties of the edited form of the GluR5 subunit. We never encountered a doubly rectifying shaped $I-V$ curve, which is characteristic of unedited channels, although the present RT-PCR data revealed the unedited form of GluR5 and GluR6 subunits in the TG. This discrepancy could be explained if the GluR5(Q) subunit coexists in the same cell with GluR5(R) or GluR5(R)/KA-2 channels. Coexpression of the edited and unedited form of the GluR5 or GluR6 subunits has been reported to make the $I-V$ relationship more linear and the divalent permeability low (Sommer et al., 1992; Köhler et al., 1993).

\section{Whole-cell current noise analysis}

To estimate the mean channel conductance, we plotted the variance of whole-cell kainate current noise against mean inward current. Figure $7 A$ shows the onset of the steady-state current response to $200 \mu \mathrm{M}$ kainate after treatment with Con A (300 $\mu \mathrm{g} / \mathrm{ml})$. All of the current-variance relationships obtained were linear rather than parabolic, indicating that the probability of channel opening was low during the steady-state response to kainate. Mean conductance was derived according to $\gamma=\delta^{2} /$ $\left[\mu\left(V_{\mathrm{c}}-V_{\mathrm{rev}}\right)\right]$, where $\gamma$ is the mean conductance, $\delta^{2}$ is the current variance, $\mu$ is the mean current, $V_{\text {rev }}$ is the reversal potential, and $V_{\mathrm{c}}$ is the holding potential. $V_{\mathrm{rev}}$ was near $0 \mathrm{mV}$ for all recordings. The mean channel conductance estimated from the slope of the variance versus mean current relationship in Figure $7 B$ was 1.5 
A

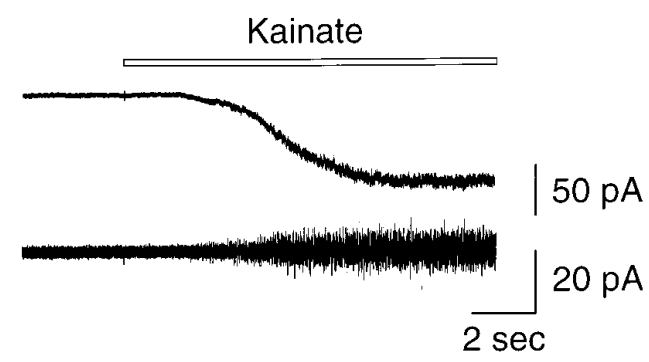

$\mathrm{B}$

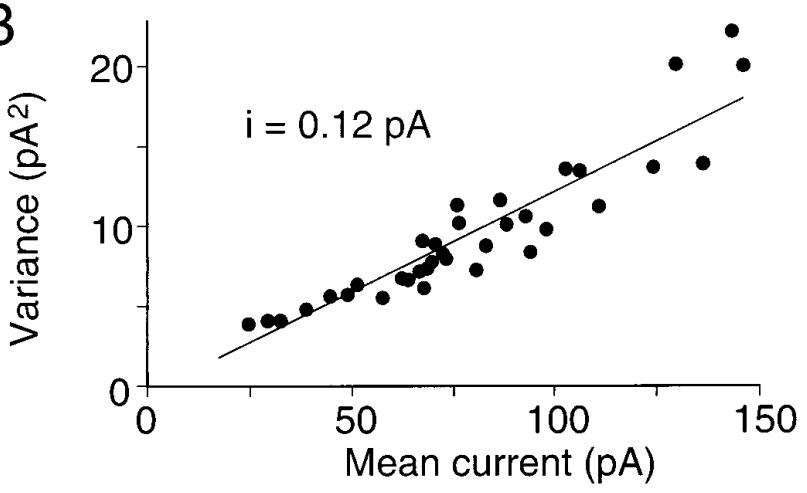

C

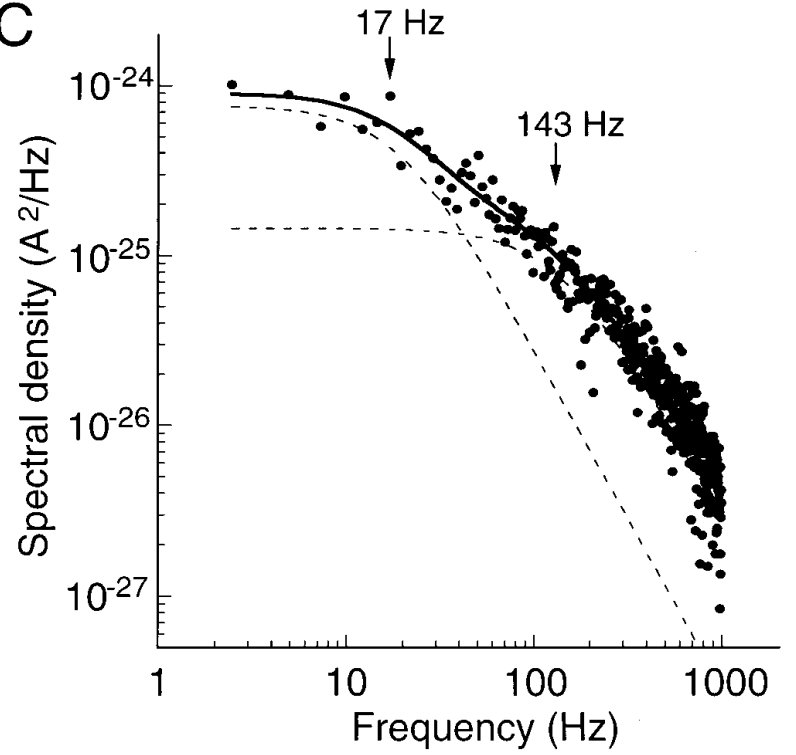

Figure 7. Whole-cell current noise analysis of kainate currents in TG neurons. $A$, Onset of the whole-cell current evoked by $200 \mu \mathrm{M}$ kainate at $-80 \mathrm{mV}$ after treatment with Con A (300 $\mu \mathrm{g} / \mathrm{ml}$ for $3 \mathrm{~min})$. The lower trace shows the high-pass-filtered record at $0.2 \mathrm{~Hz}$. $B$, Variance to mean current plots calculated from fluctuation analysis of a kainate response. Background variance was subtracted from the test variance. The straight line is the least-squares linear fit to the results. The slope of the relationship $(i)$ has a value of $0.12 \mathrm{pA}$ at $-80 \mathrm{mV}$, corresponding to a mean conductance of $1.5 \mathrm{pS}$. $C$, Power spectrum obtained from analysis of the current noise shown in $A$. The spectral density of base line noise was subtracted from that of the kainate-induced noise. The spectrum was fit with the sum of two Lorentzian components according to the equation: $G\left(f=G(0)_{1} /(1+\right.$ $\left.\left(f / f_{\mathrm{c} 1}\right)^{2}\right)+G(0)_{2} /\left(1+\left(f / f_{\mathrm{c} 2}\right)^{2}\right)$. The individual components are shown as dashed lines, and their respective cutoff frequencies $\left(f_{\mathrm{c}}\right)$ were 17 and 143 $\mathrm{Hz}$.

pS. The mean value for $10 \mathrm{TG}$ neurons was $1.6 \pm 0.2 \mathrm{pS}$. As illustrated in Figure $7 C$, the power spectrum was well fit by the sum of two Lorentzian components. Cutoff frequencies were

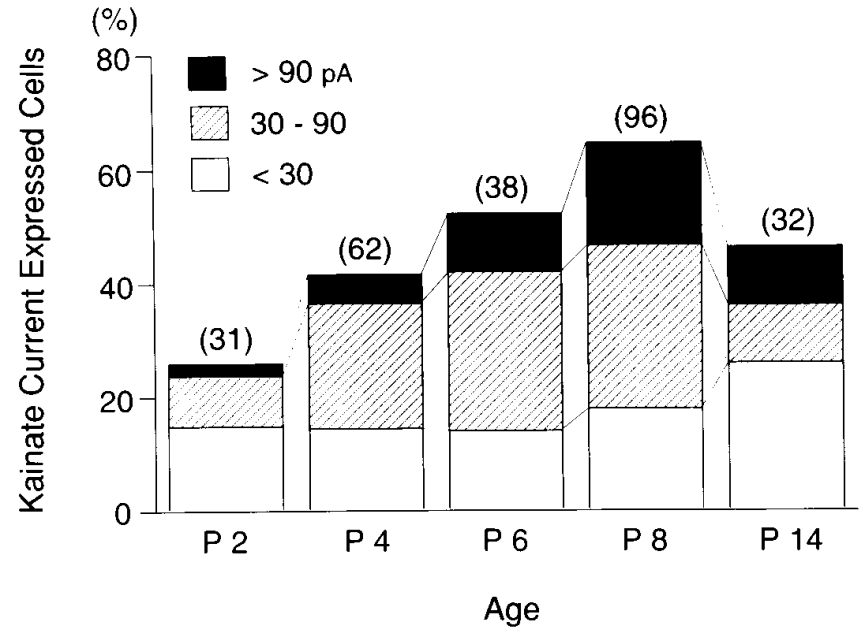

Figure 8. Postnatal developmental changes of kainate responses in smalldiameter TG neurons. Percentage of kainate current expressing cells plotted as a function of age. Numbers in parentheses show the number of cells for which kainate $(200 \mu \mathrm{M})$ was applied. Until postnatal day $8(P 8)$, kainate-sensitive TG neurons increased with development, and an increasing number of neurons had large kainate responses (peak amplitude $>90 \mathrm{pA}$ ). At later stages of development the number of neurons showing small kainate responses (peak amplitude $<30 \mathrm{pA}$ ) increased. Holding potential was $-80 \mathrm{mV}$.

$13.1 \pm 2.4$ and $127.3 \pm 12.7 \mathrm{~Hz}$, yielding mean time constants of $14.9 \pm 3.2$ and $1.1 \pm 0.1 \mathrm{msec}(n=10)$. Swanson et al. (1996) reported that (1) $\mathrm{Q} / \mathrm{R}$ site editing dramatically reduces singlechannel conductance [GluR6(Q), 5.4 pS; GluR6(R), 225 fS; GluR5(Q), 2.9 pS; GluR5(R), <200 fS] and (2) heteromeric GluR5(R)/KA-2 and GluR6(R)/KA-2 receptors have higher conductances (950 and $700 \mathrm{fS}$ ) than the respective homomeric channels. The value from TG neurons corresponds to that obtained from recombinant GluR5(R)/KA-2.

In summary, the data obtained from the Con A and CTZ sensitivities, the time course of desensitization of kainate currents, the $I-V$ relationships, and the mean channel conductance from noise analysis all point to the possibility of coassembly of GluR5(R) and KA2 subunits in TG neurons.

\section{Postnatal changes of kainate receptor subunits}

It has been reported that the GluR5 gene, in contrast to other GluRs subunits, undergoes clear qualitative changes in its expression over time and that the time course of the GluR5 expression peak is consistent with that of the period of greatest developmental plasticity (Bettler et al., 1990; Bahn et al., 1994). We examined kainate responses at various postnatal developmental ages (P2P14). The number of kainate-sensitive TG neurons increased until P8, although only small diameter cells $(<30 \mu \mathrm{m})$ responded to kainate. The peak amplitude of kainate current was small at birth $(>10 \mathrm{pA})$ and gradually increased during the first postnatal week. As shown in Figure 8, an increasing number of neurons had large kainate responses (peak amplitude $>90 \mathrm{pA}$ at $-80 \mathrm{mV}$ ) until P8. After P8, the numbers of neurons showing small kainate responses increased.

Figure 9 shows Northern blot analysis of GluR5, KA-1, and KA-2 messages at various postnatal ages (P1, P3, P7, P14, P28, and P56). The relative levels of RNA for GluR5 in the TG changed age-dependently and were changed only slightly for KA-2, whereas the RNA levels for KA-1 remained relatively constant (Fig. 9). The GluR5 $3.6 \mathrm{~kb}$ message showed a high level 
GluR5

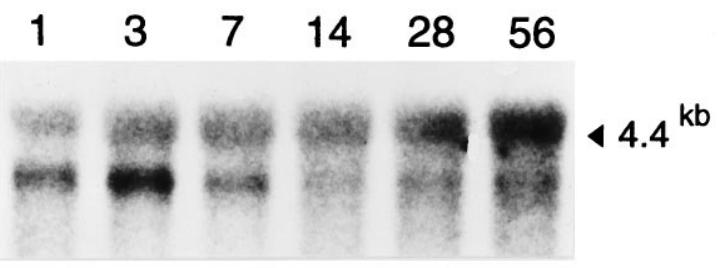

$\mathrm{KA}-1$

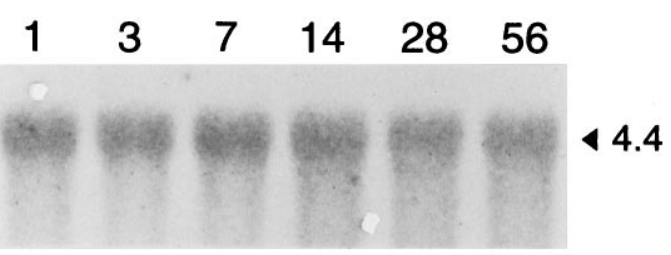

$\underline{\mathrm{KA}-2}$

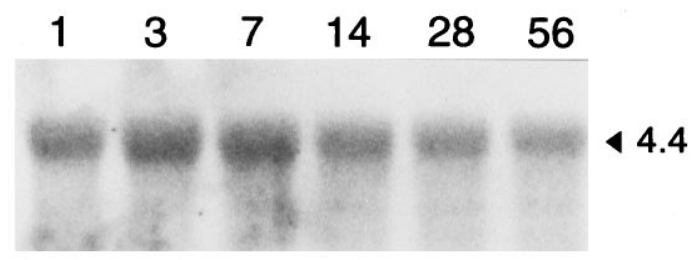

Figure 9. Northern blot analysis of GluR5, KA-1, and $K A-2$ message in $\mathrm{TG}$ at various postnatal ages. Total RNAs (10 $\mu \mathrm{g}$ per lane) isolated from TGs of P1, P3, P7, P14, P28, and P56 rats were hybridized with cDNA probes specific for GluR5, KA-1, or KA-2 under stringent conditions. Numbers on the right represent molecular size as derived from an RNA standard.

at birth and reached its peak by $3 \mathrm{~d}$, subsequently dropping to a barely detectable level in the adult. In contrast, $4.4 \mathrm{~kb}$ GluR5 message was detectable at birth and increased steadily until the adulthood. By P7 the relative abundance of the two isoforms appeared to be approximately equal. By the adulthood it was clear that the $4.4 \mathrm{~kb}$ isoform comprised the majority of the products, although there was some $3.6 \mathrm{~kb}$ product still visible. KA-2 messages also reached a peak by 3-7 d and subsequently dropped to a barely detectable level in the adult. The increase in GluR5 and KA-2 RNA correlates well with the increased number of kainatesensitive cells and increased peak amplitude of kainate-evoked currents. The changes in GluR5 and KA-2 RNA levels we have observed could reflect the appearance and disappearance of particular types of GluRs during postnatal development.

\section{DISCUSSION}

We have demonstrated that (1) all five known kainate receptor subunits are expressed to some extent, although particularly high levels of GluR5 and KA-2 RNA are observed in the TG; (2) there is an obvious similarity between the features of native kainate receptor channels in TG neurons and of recombinant channels assembled from the heteromeric GluR5(R)/KA2 receptors with respect to the specific physiological and pharmacological properties of currents gated by kainate; and (3) the age-dependent increase in GluR5 and KA-2 RNA levels in the TG is correlated with an increased number of kainate-sensitive cells during postnatal development. Our results suggest that the heteromeric GluR5/KA2 combination actually occurs in native neurons.

\section{AMPA receptors in TG neurons}

Low levels of GluR1-4 RNA were detected in the TG, consistent with other studies on cranial and spinal ganglia (Bettler et al., 1990; Sato et al., 1993; Niedzielski and Wenthold, 1995). In contrast, the present physiological and pharmacological experiments showed that AMPA (up to $1 \mathrm{~mm}$ ) did not induce any detectable responses in TG neurons. One concern might be that AMPA responses may not be detected in the present experiments because of the speed of solution exchange. Very rapid desensitization of AMPA receptor channels ( $\sim 10 \mathrm{msec}$, Colquhoun et al., 1992; Jonas and Sakmann, 1992) has been reported with a fast perfusion technique with outside-out patches. However, significant functional expression of AMPA receptors in the TG seems unlikely, based on the following facts: (1) AMPA is a potent agonist at AMPA receptors that produces rapidly and strongly desensitizing responses, whereas kainate is a low-affinity agonist at AMPA receptors that produces nondesensitizing responses with whole-cell recording (Keinänen et al., 1990; Sommer et al., 1991); (2) all kainate responses in TG neurons have desensitization, which was not modulated by CTZ but was modulated by Con A; and (3) inhibition of kainate responses after prolonged application of AMPA or quisqualate (cross-desensitization; Patneau and Mayer, 1991) was not observed in TG neurons. Possibilities that might account for the presence of GluR1-4 would be receptors on glia in the TG and/or expressed AMPA receptor subunits that are not correctly assembled, transported to, or inserted into the plasma membrane of TG neurons.

\section{Composition of glutamate receptor subunits in TG neurons}

The heteromeric recombinant GluR5(R)/KA-2 channels matched the native kainate receptor channels in all functional properties, and high levels of expression of GluR5 and KA-2 RNAs were detected in the TG. This is consistent with the fact that the functional properties of ion channels are highly dependent on the level of expression (Geiger et al., 1995). On the other hand, single-cell PCR analysis suggests that native AMPA responses are likely to result from the assembly of different combinations of subunits (Lambolez et al., 1992; Bochet et al., 1994; Geiger et al., 1995). It remains possible that the KA-1 or GluR7 subunit combines with GluR5(R)/KA-2 subunits to produce kainate receptors. The effects of KA-1 on desensitization kinetics and the behavior of receptors containing GluR5(R)/KA-2 have not been assessed in transfected mammalian cell lines. GluR7 was expected to have physiological properties similar to those observed for homomeric GluR6 subunits, based on amino acid sequence homology. However, GluR7 was found not to assemble into either functional homomeric channels or heteromeric channels with KA-1 or KA-2 in Xenopus oocytes and HEK 293 cells (Bettler et al., 1992; Lomeli et al., 1992). It would be interesting to examine the subunit composition in TG neurons by single-cell $\mathrm{PCR} /$ patch-clamp technique.

The replacement of a glutamine by an arginine in the $Q / R$ site of GluR2, GluR5, and GluR6 results in (1) a reduction in $\mathrm{Ca}^{2+}$ permeability (Hume et al., 1991; Burnashev et al., 1992), (2) a change of inward rectification because of a loss of sensitivity to intracellular polyamines (Bowie and Mayer, 1995; Kamboj et al., 1995), and (3) reduction of the single channel conductance of AMPA and kainate receptors (Swanson et al., 1996; Swanson et al., 1997). Coexpression of the edited and nonedited forms of the GluR(B), GluR5, or GluR6 subunits has been reported to change the shape of the $I-V$ relationship to become more linear (Sommer 
et al., 1992; Köhler et al., 1993), and heteromeric GluRB(Q)/ $\mathrm{B}(\mathrm{R})$ channels generate cells with low divalent permeability (Burnashev et al., 1992). Thus, some of the GluR5(Q) could coexist with GluR5(R) or GluR5(R)/KA-2 in the same cell. However, inward rectifying responses to GluR5(Q) were reported to be unaltered on cotransfection with GluR-B, and the inward rectification of GluR-D responses also was unchanged on cotransfection with GluR5(R) (Partin et al., 1993). Thus, any cross-assembly between AMPA and kainate receptor subunits seems unlikely.

KA-2 does not form functional homomeric channels, whereas coexpression of KA-2 with GluR5 or GluR6 results in channels with novel properties (Herb et al., 1992). It has been demonstrated that the KA-2 subunit causes striking effects on singlechannel conductance when coexpressed with GluR5(R) or GluR6(R) (Howe, 1996; Swanson et al., 1996). In addition, the involvement of the KA-2 subunit was found to influence the kinetics of low-affinity subunits: the channel produced by GluR5(Q)/KA-2 has shorter channel burst lengths than that of homomeric GluR5(Q) (Swanson et al., 1996) and results in more rapid desensitization than that seen in channels formed from GluR5(Q) subunits (Herb et al., 1992). Our present data suggest that the involvement of KA-2 could change sensitivity to Con A. Desensitization of glutamate receptors expressed by invertebrate muscle, vertebrate CNS, and mammalian DRG neurons as well as of recombinant homomeric GluR5(Q), GluR5(R), and GluR6(Q) is eliminated almost completely by Con A (Huettner, 1990; Wong and Mayer, 1993; Howe, 1996; Swanson et al., 1996). In TG neurons, however, treatment with Con A did not eliminate desensitization completely. Interestingly, Con A-insensitive desensitizations were visible in domoate responses of both heteromeric GluR5(R)/KA-2 and GluR6(R)/KA-2 channels (Swanson et al., 1996). The abundantly and widely expressed KA-2 subunit could lead to functional diversity in kainate receptor channels.

DRG neurons are known to respond to AMPA (Huettner, 1990), which has been explained by homomeric expression of GluR5(Q). This raises the question of whether the lack of AMPA response in TG depends on the receptor isoform. It has been reported that GluR5(Q) forms functional homomeric AMPAactivated receptors (Sommer et al., 1992) and that kainate receptors become sensitive to AMPA when GluR5 coassembles with KA-1, or GluR6 assembles with KA-1 or KA-2 (Herb et al., 1992). The involvement of the KA-2 subunit was found to influence agonist affinity for the low-affinity subunits [e.g., the $\mathrm{EC}_{50}$ for kainate activation of homomeric GluR6(R) channel is $0.47 \mu \mathrm{M}$ and GluR6(R)/KA-2 channels is $1.62 \mu \mathrm{M}$ (Howe, 1996)]. Thus, it is likely that the KA-2 subunit influences AMPA affinity, depending on the receptor isoform coexpressed.

\section{Functional significance of kainate receptors on TG neurons}

There is no direct electrophysiological evidence for an involvement of kainate receptors in synaptic transmission. However, there is a general belief that kainate receptors play a role in nociception, based on the facts that (1) kainate responses have been identified by using the whole-cell patch-clamp technique in a subpopulation of smaller diameter DRG neurons; (2) C-fibers arise from small to intermediate diameter sensory neurons (Harper and Lawson, 1985), and most axons in the C-fiber range convey nociceptive or thermoreceptive information; and (3) the kainate receptor seems to be expressed preferentially on the afferent axons rather than on the DRG cell body, because local administration of kainate is less effective when applied at the
DRG (Agrawl and Evans, 1986; Tölle et al., 1993). However, it is not known whether functional kainate receptors reside on presynaptic terminals, where kainate receptors may function as presynaptic autoreceptors.

An involvement of kainate receptors in development has been suggested. Bettler et al. (1990) first described the regulated expression of GluR5 in the developing mouse brain, where a peak in expression of high-affinity kainate binding sites occurred in the first 2 weeks after birth, coincident with periods of synaptogenesis. We observed a marked transient increase of GluR5 RNAs in the TG, and the increase of GluR5 expression correlated well with both an increased number of kainate-sensitive cells and an increased peak amplitude of kainate-evoked currents. Trigeminal axons, however, already have reached their peripheral and central targets by day E11 (Stainier and Gilbert, 1990; Li et al., 1994); thus, the changes in GluR5 RNA levels we have observed seem not to reflect the formation of synapses or the generation of new neuronal networks during synaptogenesis. The GluR5 subunit may play a role in synapse refinement. In the developing spinal cord (at E18-E21) of the rat, Seebach and Ziskind-Conhaim (1994) showed that a significant percentage of motoneurons initially was innervated by inappropriate primary afferents of antagonistic muscles, but the percentage of functionally inappropriate synapses was reduced within 3-5 d after birth, which was correlated with an increase in the frequency of spontaneous activity and the onset of myelination. Endogenous lectins expressed in both CNS and PNS neurons, which bind to sugar residues of cellular surface glycoproteins and carbohydrate moieties, are believed to play important roles in neuron-neuron or neuronglia interactions and are good candidate modulators of receptor desensitization in vivo.

\section{REFERENCES}

Agrawl SG, Evans RH (1986) The primary afferent depolarizing action of kainate in the rat. Br J Pharmacol 87:345-355.

Bahn S, Volk B, Wisden W (1994) Kainate receptor gene expression in the developing rat brain. J Neurosci 14:5525-5547.

Bernard A, Khrestchatisky M (1994) Assessing the extent of RNA editing in the TMII regions of GluR5 and GluR6 kainate receptors during rat brain development. J Neurochem 62:2057-2060.

Bettler B, Boulter J, Hermans-Borgmeyer I, O'Shea-Greenfield A, Deneris ES, Moll C, Borgmeyer U, Hollmann M, Heinemann S (1990) Cloning of a novel glutamate receptor subunit, GluR5: expression in the nervous system during development. Neuron 5:583-595.

Bettler B, Egebjerg J, Sharma G, Pecht G, Hermans-Borgmeyer I, Moll C, Stevens CF, Heinemann S (1992) Cloning of a putative glutamate receptor: a low affinity kainate-binding subunit. Neuron 8:257-265.

Bochet P, Audinat E, Lambolez B, Crépel F, Rossier J, Iino M, Tsuzuki K, Ozawa S (1994) Subunit composition at the single-cell level explains functional properties of a glutamate-gated channel. Neuron 12:383-388.

Bowie D, Mayer ML (1995) Inward rectification of both AMPA and kainate subtype glutamate receptors generated by polyamine-mediated ion channel block. Neuron 15:453-462.

Burnashev N, Monyer H, Seeburg PH, Sakmann B (1992) Divalent ion permeability of AMPA receptor channels is dominated by the edited form of a single subunit. Neuron 8:189-198.

Colquhoun D, Jonas P, Sakmann B (1992) Action of brief pulses of glutamate on AMPA/kainate receptors in patches from different neurones of rat hippocampal slices. J Physiol (Lond) 458:261-287.

Egebjerg J, Heinemann SF (1993) $\mathrm{Ca}^{2+}$ permeability of unedited and edited versions of the kainate selective glutamate receptor GluR6. Proc Natl Acad Sci USA 90:755-759.

Egebjerg J, Bettler B, Hermans-Borgmeyer I, Heinemann S (1991) Cloning of a cDNA for a glutamate receptor subunit activated by kainate but not AMPA. Nature 351:745-748.

Geiger JRP, Melcher T, Koh D-S, Sakmann B, Seeburg PH, Jonas P, Monyer H (1995) Relative abundance of subunit mRNAs determines 
gating and $\mathrm{Ca}^{2+}$ permeability of AMPA receptors in principal neurons and interneurons in rat CNS. Neuron 15:193-204.

Harper AA, Lawson SN (1985) Conduction velocity is related to morphological cell type in rat dorsal root ganglion neurones. J Physiol (Lond) 359:31-46.

Herb A, Burnashev N, Werner P, Sakmann B, Wisden W, Seeburg PH (1992) The KA-2 subunit of excitatory amino acid receptors shows widespread expression in brain and forms ion channels with distantly related subunits. Neuron 8:775-785.

Hollmann M, O'Shea-Greenfield A, Rogers SW, Heinemann S (1989) Cloning by functional expression of a member of the glutamate receptor family. Nature 342:643-648.

Howe JR (1996) Homomeric and heteromeric ion channels formed from the kainate-type subunits GluR6 and KA2 have very small, but different, unitary conductances. J Neurophysiol 76:510-519.

Huettner JE (1990) Glutamate receptor channels in rat DRG neurons: activation by kainate and quisqualate and blockade of desensitization by Con A. Neuron 5:255-266.

Hume RI, Dingledine R, Heinemann SF (1991) Identification of a site in glutamate receptor subunits that controls calcium permeability. Science 253:1028-1031.

Jonas P, Sakmann B (1992) Glutamate receptor channels in isolated patches from CA1 and CA3 pyramidal cells of rat hippocampal slices. J Physiol (Lond) 455:143-171.

Kamboj SK, Swanson GT, Cull-Candy SG (1995) Intracellular spermine confers rectification on rat calcium-permeable AMPA and kainate receptors. J Physiol (Lond) 486:297-303.

Keinänen K, Wisden W, Sommer B, Werner P, Herb A, Verdoorn TA, Sakmann B, Seeburg PH (1990) A family of AMPA-selective glutamate receptors. Science 249:556-560.

Köhler M, Burnashev N, Sakmann B, Seeburg PH (1993) Determinants of $\mathrm{Ca}^{2+}$ permeability in both TM1 and TM2 of high affinity kainate receptor channels: diversity by RNA editing. Neuron 10:491-500.

Lambolez B, Audinat E, Bochet P, Crépel F, Rossier J (1992) AMPA receptor subunits expressed by single Purkinje cells. Neuron 9:247-258.

Li Y, Erzurumlu RS, Chen C, Jhaveri S, Tonegawa S (1994) Whiskerrelated neuronal patterns fail to develop in the trigeminal brainstem nuclei of NMDAR1 knockout mice. Cell 76:427-437.

Lomeli H, Wisden W, Köhler M, Keinänen K, Sommer B, Seeburg PH (1992) High-affinity kainate and domoate receptors in rat brain. FEBS Lett 307:139-143.

Niedzielski AS, Wenthold RJ (1995) Expression of AMPA, kainate, and NMDA receptor subunits in cochlear and vestibular ganglia. J Neurosci 15:2338-2353.

Partin KM, Patneau DK, Winters CA, Mayer ML, Buonanno A (1993) Selective modulation of desensitization at AMPA versus kainate receptors by cyclothiazide and Concanavalin A. Neuron 11:1069-1082.

Paschen W, Schmitt J, Dux E, Djuricic B (1995) Temporal analysis of the upregulation of GluR5 mRNA editing with age: regional evaluation. Dev Brain Res 86:359-363.

Paternain AV, Morales M, Lerma J (1995) Selective antagonism of AMPA receptors unmasks kainate receptor-mediated responses in hippocampal neurons. Neuron 14:185-189.

Patneau DK, Mayer ML (1991) Kinetic analysis of interactions between kainate and AMPA: evidence for activation of a single receptor in mouse hippocampal neurons. Neuron 6:785-798.
Patneau DK, Wright PW, Winters C, Mayer ML, Gallo V (1994) Glia cells of the oligodendrocyte lineage express both kainate- and AMPApreferring subtypes of glutamate receptor. Neuron 12:357-371.

Puchalski RB, Louis J-C, Brose N, Traynelis SF, Egebjerg J, Kukekov V, Wenthold RJ, Rogers SW, Lin F, Moran T, Morrison JH, Heinemann SF (1994) Selective RNA editing and subunit assembly of native glutamate receptors. Neuron 13:131-147.

Robinson HPC, Sahara Y, Kawai N (1991) Nonstationary fluctuation analysis and direct resolution of single channel currents at postsynaptic sites. Biophys J 59:295-304.

Ruano D, Lambolez B, Rossier J, Paternain AV, Lerma J (1995) Kainate receptor subunits expressed in single cultured hippocampal neurons: molecular and functional variants by RNA editing. Neuron 14:1009-1017.

Sato K, Kiyama H, Park HT, Tohyama M (1993) AMPA, KA, and NMDA receptors are expressed in the rat DRG neurones. NeuroReport 4:1263-1265.

Seebach BS, Ziskind-Conhaim L (1994) Formation of transient inappropriate sensorimotor synapses in developing rat spinal cords. J Neurosci $14: 4520-4528$.

Sommer B, Köhler M, Sprengel R, Seeburg SH (1991) RNA editing in brain controls a determinant of ion flow in glutamate-gated channels. Cell 67:11-19.

Sommer B, Burnashev N, Verdoorn TA, Keinänen K, Sakmann B, Seeburg PH (1992) A glutamate receptor channel with high affinity for domoate and kainate. EMBO J 11:1651-1656.

Stainier DY, Gilbert W (1990) Pioneer neurons in the mouse trigeminal sensory system. Proc Natl Acad Sci USA 87:923-927.

Swanson GT, Feldmeyer D, Kaneda M, Cull-Candy SG (1996) Effect of RNA editing and subunit co-assembly on single-channel properties of recombinant kainate receptors. J Physiol (Lond) 492:129-142.

Swanson GT, Kamboj SK, Cull-Candy SG (1997) Single-channel properties of recombinant AMPA receptors depend on RNA editing, splice variation, and subunit composition. J Neurosci 17:58-69.

Tölle TR, Berthele A, Zieglgänsberger W, Seeburg PH, Wisden W (1993) The differential expression of 16 NMDA and non-NMDA receptor subunits in the rat spinal cord and in periaqueductal gray. J Neurosci 13:5009-5028.

Vyklicky Jr L, Benveniste M, Mayer ML (1990) Modulation of $N$-methyl-D-aspartic acid receptor desensitization by glycine in mouse cultured hippocampal neurones. J Physiol (Lond) 428:313-331.

Wenthold RJ, Trumpy VA, Zhu W-S, Petralia RS (1994) Biochemical and assembly properties of GluR6 and KA2, two members of the kainate receptor family, determined with subunit-specific antibodies. J Biol Chem 269:1332-1339.

Werner P, Voigt M, Keinänen K, Wisden W, Seeburg PH (1991) Cloning of a putative high-affinity kainate receptor expressed predominantly in hippocampal CA3 cells. Nature 351:742-744.

Wilding TJ, Huettner JE (1997) Activation and desensitization of hippocampal kainate receptors. J Neurosci 17:2713-2721.

Wisden W, Seeburg PH (1993) A complex mosaic of high-affinity kainate receptors in rat brain. J Neurosci 13:3582-3598.

Wong LA, Mayer ML (1993) Differential modulation by cyclothiazide and Concanavalin A of desensitization at native $\alpha$-amino-3-hydroxy-5methyl-4-isoxazolepropionic acid- and kainate-preferring glutamate receptors. Mol Pharmacol 44:504-510. 